\title{
The Impact of Basic Literacy Program to Create a Learning Society
}

\author{
Heryanto Susilo \\ Nonformal Education Department \\ Universitas Negeri Surabaya \\ Surabaya, Indonesia \\ Corresponding e-mail: heryantosusilo@unesa.ac.id
}

\begin{abstract}
Basic literacy is a program that focused on reading, writing and counting skill as an effort of adult low literacy skill improvement or illiteracy age 15-59. This research aim to determine the implementation, analyses result, and the effect of learning society creation, supporting and inhibiting factors of basic literacy program on SKB Malang target group. In this research applied qualitative method, research subject were student, tutor, and program organizer. Research result showed that basic literacy program implementation referred to 10 learning community standards namely: 1) student, 2) tutor, 3) learning instructor, 4) learning place, 5) learning infrastructure, 6) learning group, 7) learning formulation, 8) learning funding, 9) learning program, 10) learning result. Program results referred to three domains covered cognitive, affective and psychomotor aspects. Program affected to student if they can implement its basic literacy program result to daily live supporting factor in this program was internal factor namely motivation and family support and external factor was supporting learning environment, flexible learning hours, conducive local area, and support from village officer. While for inhibiting factors which can hampered the achievement of program purposes were learning hours adjusted student's activity, lack of tutor's advocacy, lack of infrastructure and advocacy funding.
\end{abstract}

Keywords: basic literacy, learning society

\section{INTRODUCTION}

In accordance with presidential instruction No. 5 in 2006 about Gerakan Nasional Percepatan Penuntasan Wajib Belajar Pendidikan Dasar Sembilan Tahun dan Pemberantasan Buta Aksara (GNP-PWB/PBA) which has been followed up by The Regulation of The Minister of National Education number 35 year 2006 about Technical implementation of GNP-PWB/PBA and Literacy Initiative for Empowerment (LIFE) UNESCO-UNLD, Ministry of Education and Culture through The Directorate of Management of Community Education, Directorate General of Early Childhood Education provided literacy education programs to eradicates illiteracy in Indonesia. The purpose of this effort is to continuously improve the community literacy skill thus the low-literacy people could increase or at least maintain their literacy skill.

Indonesia has three education channels which are formal education, non-formal education and informal education. Illiteracy includes in non-formal education. Meanwhile the notion of the non-formal education is an education channel outside of formal education that applied in a structured and graded way. The outcomes of non-formal education is equal with the formal education program after going through an equivalency assessment process by an agency designated by the Government or the Regional Government refer with the national standard of education.

One of the example of non-formal education that aims to eradicate illiteracy is Functional Literacy. It is an extramural education that separated with the school and specified for individual without reading, writing, and counting skills. So they can use the expertise of it in their lives. These skills can they use to struggle in the world.

Based on the introduction above, the researcher wants to do research about the implementation, outcomes, impact, factor endowments, and restricting factors of basic literacy programs towards the creation of learning community in the guided group SKB Malang district.

\section{METHODS}

Method is the most important step and influence the outcome of the research which was held. Because the description of the research object contained within the data being reported. Descriptive research with qualitative approach are the methods that used in this research. Descriptive research is a research that gives description of the object which examined systematically. Qualitative research usually presents data in the form of words, sentences or images that has meaning beyond number or frequency.

Qualitative research requires an intense relation with the informant and the awareness with the environment, so researcher gains a deeper understanding of realities and real-life conditions. So that the goal of the research is to describe the event within the field in a great depth and detail, and finally linked it into the existing theory.

In this approach, research method will be used to examine objects that are in a natural condition, in which the researcher is as a key instrument for this 
research, data collection will be done in a triangulation (combined), with an inductive data analysis, and the results of qualitative research are more emphasis to the meaning than on generalization (Sugiyono, 2014:1). According to Bogdan and Taylor (Moleong, 2005:4) qualitative is a research procedure that provides descriptive data in the form of the written word or spoken transcription of people and behavior that can be observed. This research was held in the village of Sidodadi, Lawang, Malang district, Jati study group is used as a place to learn basic literacy studies and it also one of the basic literacy program implementation. The reason why the researcher choose this location because the existence of Jati study group in this village which has been doing basic literacy program which is fostered by SKB Malang. According to Spradley (Sugiyono, 2014:68) the subject of the study is everyone involved in any social situation. In this study the subjects of the research consists of a program manager, a tutor, and ten Jati's basic literacy learners study group program.

In accordance with the research method, data analysis technique used by the researcher is the qualitative data analysis. The ability of the researcher to connecting facts, data, and information is used as a tool to collecting data for the qualitative analysis. Related with this study, observation of objects that will be examined first, and then identify the issues that need to be researched.

In this study, the data analysis will be done during the data collection process because in qualitative data analysis the data is more focused during the field activity with the data collection and after it finished in a specific period (Sugiyono, 2006:246).

Validity technique examination is crucial to know which that data is valid or not. The examination technique required to establish the validity of the data. The inspection implementation technique based on a number of specific criteria. According to Loncoln and Guba (1985) and (Areyouredsquirrel, 2007:17-21) there are at least 4 standard of type: credibility, transfermabilitas, dependabilitas and transfermabilitas.

\section{RESULT AND DISCUSSION}

After the researcher has collected data through interviews, observation and documentation, then the researcher do the data processing, in this case describes about implementation, result, impact, factor endowment, the basic literacy program of an inhibitor factor against the creation of a learning society SKB Malang. The implementation of the basic literacy program in a group of small-scale SKB Malang implemented with 10 components based on benchmark public education in achieving the learning objectives. (Kuncoro, 2005:11)

Basic literacy program is a program that focuses on the ability of reading, writing and counting skills as an effort to increase the ability of low-literacy adult in the range of age; $15-59$ years and above, so the skills can eventually support the daily activities in their lives in family and community.

Basic Literacy programs as the activity that provides basic capabilities for citizen who want to learn gradually can changes a person's behavior. This is in accordance with the statement of Gagne (1970) in The book The Conditions of Learning, suggests that learning is a process, it is not naturally applied to a person, but a person should struggle with his/her own effort to reach the learning target that they want to achieve. Based on that statement, learning is a deliberate attempt by someone who aims to achieve their learning objectives.

The main objective of basic literacy program is to change the learning behavior of community generally, because the target is to improve the disposition and ability. The disposition is refer to the attitude, knowledge, skills and values (Sudjana 2005). As the results of the Basic Literacy program is to improve the citizen learning process/citizen learning skills in various environments, such as the daily activity, work, and life in General.

Basic Literacy Programs if connected with the educational purpose classification (Taxonomy of educational objectives), then the ability of citizens learning consists of three categories which are cognitive domain, affective, and psychomotor.

The cognitive domain which belonged to basic literacy resident learner after following the program learner is able to read, write and counting. For example resident learners can already write a recipes, make notes, and create a cake recipe. These capabilities are evidence that the resident learners can implement the results of their studies to support his everyday life. Thus cognitive ability that is owned by residents of the student is able to be conserved for everyday life. On the affective domain in accordance with the statement (Sudjana, 2005:99) the changes are related to the interests, attitudes, values, appreciation and adaptability. After the basic literacy program, resident learners has a high learning motivation so that their ability remains sustainable and implemented in everyday life. On the affective domain in accordance with the statement (Sudjana, 2005:99) the changes are related to the interests, attitudes, values, appreciation and adaptability. After the basic literacy program, resident learners has a high learning motivation so that their ability is remains sustainable and implemented in everyday life. Affective abilities possessed by citizens of such learning can support their work, activities, and in daily life.

This proves that the learning citizens has a high motivation to develop their capabilities and quality. In psychomotor domain, the citizens were able to implement literacy ability is basically in support of the activities of the productively. The activities include the ability to write business stuff, the ability to read the needs or household and the arithmetic is implemented through practice/job. 
Basic Literacy program indirectly provided a positive impact to the creation of community learning in Group construction of SKB Malang, as citizens learn capable of writing, reading and arithmetic to implemented in everyday life. The impact of a program especially PLS learning is that the citizen are able to apply his ability for everyday life.

This is in accordance with Retman statement in (Sudjana 2005). He stated that learning activities needs to give priority to solving the problems facing problems because learners will be encouraged to use their minds creatively and work intensively to solve the problems encountered in his life. Retman's opinion is supported by Paulo Freire; in learning activities that are effective is when problem possing efforts became the core of the learning activities of the group. Basic literacy program is also has a role as an effort of learning empowerment for who have been following that program. This thing is accordance with Kindervater (1979) statement, he said that empowerment is any attempt which aims to arousing the awareness of education, understanding and sensitivity of group members (resident learner) to the development of social, economic or political, and so in the end they has the ability to improve and enhance their level in the society. So that the influence of literacy program accordance with Sudjana statement (2005: 70) he said that learning could be stated as a successful thing is when the result has a huge impact to the learners. That impact is relates to the increasing of the standard of living, such as learners in the work environment, the efforts of educate others, and their participation in community development or in their environment.

In each program execution there must be some factors that can support the program, there are several supporting factors in the Basic Literacy programs towards the creation of Community Learning in Group Construction of SKB Malang. There is internal and there is also external supporting factors that helps the implementation, internal supporting factors derived from the resident learners and tutors, the first internal supporting factors are: Resident learners of basic literacy programs has the enthusiasm and spirit to implement the results of the program. The motivation of resident learners as the psychological factor, triggers the activation of the literacy learning process. Without any motivation, no matter how good the strategy and tool the tutor uses when they were teaching, the study process would not be a warmth, participative, and accurate process. Tutors should also continuously provide motivation and rewards to the resident learners that has a strong self-confidence to keep learning without limits of age (Wahyudin in the journal educational research, vol. 13, no. 1, April 2012), namely the support of families during the following and post program citizens learning supported by a family member who's a proven (husband, children, grandchildren and other family). Supports from their family is also important to their motivation. For example: reminiscent of a schedule of learning, reminding about the $\mathrm{KD}$ program, and providing free time to the resident learners. This program became a valuable opportunity for the resident learners. Some of them wants to improve their knowledge and skill. The attitude of citizens towards learning difficulties or barriers are in fact heavily dependent on circumstances and attitude to their environment (Djumarah, 2008:121). Furthermore the quality of tutors is also determine the success of the realization of the program.

If the tutors do not have good quality, then of course tutor cannot imply the studies objective correctly. Tutors are not just needs to be a professional in the processing process of learning, but the main thing is how to prepare the resident learners to be human that has a clear future. Which means when the learning process takes place, what is the meaning of the process of learning to the resident learners, their families and society? Will it support their economic and social life? (kamil, Gus, 2009:66). In addition to the internal supporting factors there are also external supporting factors, the first external suporting factors are: a supportive learning environment if the environment is supportive especially when the activities happen, it is very helpful to the learning activities that conducted by resident learners facilitated by the tutors. The flexibility of a customized learning time observing the learners especially females (adults) then the flexibility of learning time could be mutually agreed between resident learners and tutors. And it does not sealed the possibility of the change of learning time accordance with the agreement of incidentally. So the learner could arranged their time properly. The local environment that is conducive and the support of the head of the village and other support resources that can be found in the community are also helps this program to be held. One of them, the leader of the village of Wonorejo Sidodadi, organization and villagers. Through the statement of the leader of the village say that they are very grateful when their village served as the location for Basic Literacy learning. The fact that illiteracy citizen are still many and during this time the community has felt the benefits with the knowledge gained to improve the standard of living. By having a good acceptance from the leader of the village and the local community, it is very helpful for this program. Some notes that must be considered in the development of a society, that in the development of non-formal education, the executor needs citizen's support and also from the local governments, community leaders and citizen organization (kamil, mustofa, 2009:59). In addition to the other factors described above, researchers in the implementation of the basic literacy program towards the creation of an assisted learning group society SKB Malang, there is also an inhibitor factor in this literacy program. The first one: there is an activity that inhibits the learning process, these conditions result a delay in 
the learning program and also reducing the further learning time. Lack of the assistance from the tutor in the intensive learning process is also being an obstacle for the resident learners who are weak in study. Not all the resident learners has a great learning skill, so they need a special guidance from tutors, and the last is the lack of facilities to improve the literacy of the resident learners. The appearance of study facilities are crucial in literacy study program (Juknis dikmas BP-PAUDNI Regional IV Banjarbaru). Sudjana stated that the appearance of facilities should be fulfilled for allow the group learning activities can possibly happened (Diklus, Jurnal pendidikan Luar Sekolah Volume 14, Nomor 1, Maret 2010). The geographical conditions of the village and the village of Wonorejo Sidodadi, places of learning, limited facilities and infrastructure, and the lack of a place to learn as a location that allows the resident learners could be gathered together to follow the study, resident learners learning activities must be conducted by sitting down on the floor.

While in the study principle, learning should be supported by tools or media that can be heard and seen by the resident learners, sufficient air circulation, there is freedom of choice of appropriate seating pleasure each seating rules, which allow the occurrence of many communication direction, the freedom to use the best available facilities, the opportunity to complete a learning tool, either for yourself or for the common good (Marzuki , Saleh, 2012:191).

But the place of learning can be done anywhere, the important thing is conductivity to improving the ability of learning, and the accuracy in choosing a place to learn, is indispensable in order to create a comfortable atmosphere which is enlightening and empowering the learners (Juknis Dikmas BPPAUDNI Regional IV Banjar baru 2015). And lack of mentored funds as a tool to improve the ability of resident learners in everyday life. To maximize the basic capabilities and the skills in home/community, so the program needs some funding for mentoring the effort. This attempt is to avoid the ability of literacy for being annihilated post program.

\section{CONCLUSION}

The results of the Basic Literacy Program refers to the three aspects include: 1) the cognitive aspect which is fulfilled when the learners are able to write, reading and counting, 2) The affective aspect is fulfilled when the learners had the spirit to develop their own capabilities, 3) aspects of psychomotor is fulfilled when the learners are able to apply the skill that they achieved in their daily life productively. Basic Literacy Construction SKB Groups Program Malang had impact to the resident learners, and they are able to apply their new skills such as reading, writing, and counting in their daily life. There are some factors that supports the success of this program. Those factors are: Internal factors (high study motivation, the supports from the family and cooperative tutor) and external factor (a good study environment, and the flexibility of time that adjusted by the tutors and the learners, and a conducive environment). There are some resistor factors in this basic literacy programs: the crash of time between study and working hour, the lack of mentoring from tutor especially for the less-good performance learners, and the lack of facilities for the resident learners.

\section{REFERENCES}

[1] Departemen Pendidikan Nasional. (2005). Penyelenggaraan Program Keaksaraan Fungsional. Jakarta: Direktorat Jendral Pendidikan Luar Sekolah \& Pemuda

[2] Diklus. (2010). PLS FIP Universitas Negeri Yogyakarta. Jurnal Pendidikan Luar Sekolah, 14, 1.

[3] Direktorat Pembinaan Pendidikan Masyarakat, Ditjen PAUDNI, Kementerian Pendidikan dan Kebudayaan. Petunjuk Teknis Penyelenggaraan Kelompok Percontohan Pembelajaran Pendidikan Masyarakat. Banjarbaru, Tahun 2015

[4] Djumarah, Syaiful Bahri. (2008). Psikologi Remaja. Jakarta: Rineka Cipta

[5] Joesoef, Soelaiman. (2004). Konsep Dasar Pendidikan Luar Sekolah, Jakarta: Bumi Aksara

[6] Kamil, Mustofa. (2009). Pendidikan Nonformal: Pengembangan Melalui Pusat Kegiatan Belajar Mengajar (PKBM) di Indonesia (Sebuah Pembelajaran Dari Kominkan Jepang). Bandung: Alfabeta [7] Kindervater, S. 1979. Nonformal Education as An Empowering Proses Whice Csae Studies From Indonesia and Thailand. Massachusetts: Centre for Internasional Education University of Massachusett

[8] Kusnadi, dkk. (2003). Program Keaksaraan Dasar di Indonesia Konsep, Strategi, dan Implementasi. Jakarta: Mustika Aksara

[9] Sumardi, Kamin. (2009). Pendidikan Keaksaraan Dasar Melalui MetodeKombinasi Bagi Wanita Miskin dan Tuna Aksaradi Pedesaan Indonesia. III, 1.

[10] Yulianingsih, Wiwin; Lestari, Dwi Gunarti. (2013). Pendidikan Masyarakat. Surabaya: Unesa University

Press. 